RESEARCH ARTICLE

Published August 7, 2017

\title{
CD161 Expression ON MucosA- Associated Invariant T Cells is Reduced IN HIV-INFECTED SUBJECTS UNDERgoING Antiretroviral Therapy Who Do Not ReCOVER CD4 ${ }^{+}$T Cells
}

\section{AUTHORS}

Michael L. Freeman ${ }^{1}$, Stephen R. Morris², Michael M. Lederman ${ }^{1}$

\section{AFFILIATED INSTITUTIONS}

${ }^{1}$ Center for AIDS Research, Division of Infectious Diseases and HIV Medicine, Department of Medicine, Case Western Reserve University/University Hospitals Cleveland Medical Center, Cleveland, Ohio

${ }^{2}$ Louis Stokes Cleveland VA Medical Center, Cleveland, Ohio

CORRESPONDING AUTHOR

Michael L. Freeman

Case Western Reserve University, School of Medicine

2109 Adelbert Rd. / BRB 1048B

Cleveland, $\mathrm{OH} 44106$

Phone: 216-368-2534 / Fax: 216-368-5415

MLF62@case.edu
DOI

10.20411/pai.v2i3.136

\section{SUGGESTED CITATION}

Freeman ML, Morris SR, Lederman MM. CD161 Expression on Circulating Mucosa-Associated Invariant T Cells Is Reduced in HIV-Infected Subjects Undergoing Antiretroviral Therapy Who Do Not Recover CD4+ T Cells. Pathogens and Immunity. 2017;2(3):335-51. doi: 10.20411/pai. v2i3.136 


\section{ABSTRACT}

Background: Mucosa-associated invariant T (MAIT) cells are a recently identified class of innate-like $\mathrm{T}$ cells that are involved in the mucosal immune response. MAIT cells are characterized by expression of TCR Va7.2 and CD161. In HIV infection, there is a profound early loss of MAIT cells from the circulation that never fully recovers, even after prolonged viral control with antiretroviral therapy (ART).

Methods: We analyzed PBMCs from fresh whole blood from HIV-negative or ART-treated HIV-positive donors with full (Immune Success) or impaired (Immune Failure) CD4 ${ }^{+} \mathrm{T}$ - cell recovery by flow cytometry for T-cell markers, TCR Va7.2, and CD161. The PBMCs were cultured with or without TCR-mediated stimulation, and CD161 expression was assessed on Va7.2 $\mathrm{T}$ cells. Interferon- $\gamma(\mathrm{IFN} \gamma)$ production was assessed by intracellular cytokine staining.

Results: We found a decrease in the percentage of $\mathrm{CD}^{+} \mathrm{T}$ cells that expressed CD161 and the percentage of $\mathrm{Va} 7.2^{+} \mathrm{T}$ cells that expressed CD161, in HIV-infected individuals. We also found a significant increase in the percentage of $\mathrm{T}$ cells that were $\mathrm{Va} 7.2^{+} \mathrm{CD} 161$ - in immune failure compared to controls, accompanied by an increase in the percentage of $\mathrm{Va} 7.2^{+} \mathrm{CD} 161-\mathrm{T}$ cells that express $\mathrm{CD} 8^{+}$in donors with immune failure, but not immune success. After TCR stimulation in vitro, $\mathrm{Va} 7.2^{+} \mathrm{T}$ cells reduced expression of $\mathrm{CD} 161$, yet $\mathrm{Va} 7.2^{+} \mathrm{CD} 161$ - cells from immune failure donors retained the ability to express IFN $\gamma$ on stimulation.

Conclusions: Our findings suggest that in immune failure patients, the reduction in peripheral MAIT cells is due, at least in part, to a loss in CD161 expression, and is not merely the result of trafficking into mucosal tissues or cell death. These CD161- cells retain their function.

Keywords: HIV, Immune Failure, MAIT cells

\section{INTRODUCTION}

Infection with Human Immunodeficiency Virus (HIV) is well controlled in patients who adhere to a regimen of combination antiretroviral therapy (ART), with most patients achieving viral suppression. The majority of patients on ART recover $\mathrm{CD} 4^{+} \mathrm{T}$-cell numbers to over 500 cells/ $\mu \mathrm{L}$ (a population termed immune responders or immune success), but about a third of ART-treated individuals fail to recover $\mathrm{CD} 4^{+} \mathrm{T}$-cell numbers to over 350 cells $/ \mu \mathrm{L}$ (a population termed immune non-responders or immune failure) [1-4]. Patients with immune failure are most often male, older, and have lower nadir $\mathrm{CD} 4^{+} \mathrm{T}$-cell counts [ $\left.\underline{3}\right]$.

Not only do immune failure patients have lower peripheral blood $\mathrm{CD} 4^{+} \mathrm{T}$-cell counts, they also have evidence of chronic inflammation, breakdown of the gut mucosal barrier, and elevated risk of co-morbidities such as cardiovascular disease $[\underline{5}, \underline{6}]$. Plasma levels of the proinflammatory cytokine interleukin-6 (IL-6), the T-cell proliferation driver IL-7, the soluble form of the lipopolysaccharide (LPS) co-receptor CD14, and the fibrin degradation product D-dimer are all elevated in immune failure patients [ $[3,7]$. In addition, both $\mathrm{CD}^{+}$and $\mathrm{CD} 4^{+} \mathrm{T}$ cells in the circulation of immune failure donors have a more activated, differentiated phenotype than in immune success individuals $[\underline{3}, \underline{8}]$.

Another lymphocyte type that is affected during HIV infection is the mucosa-associated invariant T (MAIT) cell. MAIT cells are a recently identified T-cell population that has features of both 
innate and adaptive immunity. They are characteristically defined by expression of the T-cell receptor (TCR) invariant variable $\alpha$-chain 7.2 (Va7.2)-Ja33 [9] and high expression of the natural killer (NK) cell marker CD161 [10]. In HIV-uninfected individuals, MAIT cells can comprise around $10 \%$ of all $\mathrm{CD}^{+} \mathrm{T}$ cells in the circulation and are further enriched in the liver and in mucosal tissues $[9,11]$. Traditional $\mathrm{CD}^{+}$or $\mathrm{CD}^{+} \mathrm{T}$ cells recognize peptides presented by major histocompatibility complex (MHC) molecules I or II, respectively, but MAIT cells are specific for components of the riboflavin (vitamin $\mathrm{B}_{2}$ ) biosynthetic pathway presented by the MHC-I-related (MR) molecule MR1 [9, 12-15]. Because the riboflavin biosynthetic pathway is present in many bacteria and some fungi, this specificity allows MAIT cells to respond to microbial infection [12$14]$. The MAIT cells can kill targets in a granzyme-dependent manner $[\underline{16}, 17]$ and they produce the effector cytokines interferon- $\gamma$ (IFN $\gamma$ ) and tumor necrosis factor (TNF) as well as IL-17 and IL-22, which are 2 key cytokines in the regulation of intestinal immunity and maintenance of the gut mucosal barrier [18-20].

MAIT cells are depleted from the periphery soon after HIV infection. While numbers of MAIT cells in the gut reconstitute following ART administration, circulating MAIT-cell populations do not recover $[\underline{21}, \underline{22}]$. There is no consensus on the functionality of peripheral MAIT cells remaining in people infected with HIV, and differences in the methods of stimulation and patient populations may explain the discordant findings $[\underline{21}, \underline{23}]$.

Loss of MAIT cells is not likely to be a consequence of direct virus infection [22] and could be due to recruitment to peripheral tissues, activation-induced apoptosis, or down-regulation of CD161. The MAIT cells express many chemokine receptors such as CCR5 and CCR6 that direct them to sites of mucosal inflammation $[\underline{11}, \underline{21}, \underline{22}]$. There is also evidence that MAIT cells are susceptible to apoptosis following activation $[22,24]$. It is less clear if the loss of peripheral MAIT cells in HIV infection could be due to a phenotypic change in the cells that hide them from conventional identification $[\underline{25}, \underline{26}]$. To this end, it has been demonstrated that a Va7.2 CD161-population accumulates in individuals with chronic untreated HIV infection, and this subset retains surface receptors and transcription factors important to MAIT-cell function [21, 23]. Whether this population represents CD161-negative "ex-MAIT" cells or a newly generated Va7.2+ population is controversial, and has never been specifically examined in ART-treated individuals with impaired $\mathrm{CD}^{+} \mathrm{T}$-cell recovery.

\section{METHODS}

Donors: This work was approved by the Institutional Review Board at University Hospitals Cleveland Medical Center (\#01-98-55) in accordance with the guidelines of the Declaration of Helsinki. With written informed consent, whole blood was collected in EDTA Vacutainer tubes (BD Biosciences) from HIV-uninfected people $(\mathrm{n}=27)$, and ART-treated HIV-infected people with undetectable viremia and either $\mathrm{CD}^{+} \mathrm{T}$-cell recovery (Immune Success or Immune responders: $\mathrm{CD}^{+} \mathrm{T}$-cell counts $>500$ cells $\left./ \mu \mathrm{L}\right)(\mathrm{n}=23)$ or incomplete $\mathrm{CD} 4^{+} \mathrm{T}$-cell recovery (Immune Failure or Immune non-responders: $\mathrm{CD}^{+}{ }^{+} \mathrm{T}$-cell counts $<350$ cells $\left./ \mu \mathrm{L}\right)(\mathrm{n}=19)$. The $\mathrm{CD} 4^{+} \mathrm{T}$-cell counts were determined in the hospital clinical laboratory by flow cytometry, and CD4/CD8 ratios were determined in the research laboratory by flow cytometry. Participant characteristics are shown in Table 1. 
Table 1. Participant Characteristics.

\begin{tabular}{|l|c|c|c|c|}
\hline & \multicolumn{2}{|c|}{ HIV-positive } & \multicolumn{2}{c|}{ Total } \\
\hline & Immune Success & Immune Failure & HIV-positive & HIV-negative \\
\hline $\mathrm{N}$ (male, \%) & $23(78.3 \%)$ & $19(94.7 \%)$ & $42(85.7 \%)$ & $27(44 \%)$ \\
\hline Age (y), Median (IQR) & $52(46-55)$ & $53(49-62)$ & $53(48-56)$ & $30(25-44)$ \\
\hline Time of ART (y), Median (IQR) & $9.71(6.44-13.83)$ & $10.13(6.44-20.1)$ & $9.96(6.5-14.47)$ & NA \\
\hline $\mathrm{CD}^{+}$(cells/uL), Median (IQR) & $816(625-1009)$ & $270(230-312)$ & $475(277-848)$ & NA \\
\hline $\mathrm{CD}^{\prime} / \mathrm{CD} 8$ Ratio, Median (IQR) & $1.08(0.59-2.64)$ & $0.49(0.32-0.75)$ & $0.75(0.43-1.38)$ & $1.84(132-2.42)$ \\
\hline $\mathrm{CD}^{+}$nadir (cells/uL), Median (IQR) & $140(39-258)$ & $24(6-66)$ & $67(9.5-176.5)$ & NA \\
\hline
\end{tabular}

${ }^{a} \mathrm{ART}$, antiretroviral therapy

Tissue processing: PBMCs were purified by centrifugation over a Ficoll-Hypaque (GE Healthcare) cushion and cultured in RPMI 1640 medium supplemented with 10\% fetal bovine serum (FBS; Gibco), $1 \%$ penicillin/streptomycin (Gibco), and $1 \% \mathrm{~L}$-glutamine (Gibco) at $37^{\circ} \mathrm{C}$ and $5 \%$ $\mathrm{CO}_{2}$.

Flow Cytometry: Lymphocytes were identified by forward and side scatter, and cell identity was assessed using fluorochrome-conjugated antibodies anti-CD3 (clone SK7; eBioscience), anti-CD4 ${ }^{+}$(RPA-T4; BD), anti-CD8 (RPA-T8; BD), anti-CD161 (DX12; BD), and anti-TCR Va7.2 (3C10, BioLegend). Viable cells were gated using Live/Dead Yellow or Live/Dead Aqua viability dyes (Invitrogen) according to the manufacturer's instructions. Cells were stained for 20 minutes in the dark at room temperature, washed, and fixed in PBS containing 2\% formaldehyde. All samples were acquired on LSRII or LSRFortessa flow cytometers (BD). Cell division was assessed by labeling PBMCs with 5(6)-carboxyfluorescein diacetate succinimidyl ester (CFSE) (Molecular Probes) for 10 minutes at $37^{\circ} \mathrm{C}$. Staining was quenched by the addition of FBS for 5 minutes on ice. Cells were then washed and cultured as described.

For detection of intracellular cytokines, cells were stimulated with $50 \mathrm{ng} / \mathrm{mL}$ soluble anti-CD3 (HIT3a; BD) and $3 \mu \mathrm{g} / \mathrm{mL}$ soluble anti-CD28 (CD28.2; BD) for 24 hours at $37^{\circ} \mathrm{C}$ and $5 \% \mathrm{CO}_{2}$, in the presence of brefeldin A (GolgiPlug; BD) for the final 6 hours of stimulation. After stimulation, cells were washed, stained with viability dye and antibodies to surface antigens, then fixed and permeabilized using the Cytofix/Cytoperm kit (BD) and stained intracellularly with fluorochrome-conjugated antibody to IFN $\gamma(\mathrm{B} 27, \mathrm{BD})$.

Statistics: We compared continuous variables using the Mann-Whitney $U$ test or the Kruskal-Wallis test with Dunn's correction for multiple variables. Correlations were determined using a nonparametric Spearman test. $P$ values $\leq 0.05$ were considered statistically significant.

\section{RESULTS}

\section{Participant Characteristics}

PBMCs were harvested from whole blood from HIV-uninfected donors, or ART-treated HIV-infected donors with $\mathrm{CD} 4^{+} \mathrm{T}$-cell recovery (immune success: $>500 \mathrm{CD} 4^{+} \mathrm{T}$ cells $/ \mu \mathrm{L}$ ) or poor $\mathrm{CD} 4^{+}$ recovery (immune failure: $<350 \mathrm{CD}^{+} \mathrm{T}$ cells $/ \mu \mathrm{L}$ ). Participant characteristics are shown in Table 1. Although our healthy control cohort was not well-matched to the HIV-infected groups, we 
have found that neither age (HIV- $r=-0.2194, P=0.3393$; $\mathrm{HIV}^{+} r=-0.1623, P=0.4093$; Spearman analysis) nor sex (HIV- $P=0.7675 ; \mathrm{HIV}^{+} P=0.2038$; Mann-Whitney) had an effect on MAIT cell proportion; thus we are confident in the comparisons in this study.

\section{Reduction of CD161+ cells}

MAIT cells are often characterized by their co-expression of the NK cell marker CD161 and TCR Va7.2. The MAIT cells are $\mathrm{CD}^{+}$and are most often $\mathrm{CD}^{+}$, but they can also be $\mathrm{CD} 4^{+}$or double negative (DN; CD4-CD8-) $[\underline{10}, \underline{27}]$. Therefore, we gated on total live CD3 ${ }^{+}$cells and examined CD161 and Va7.2 expression in PBMCs from healthy control, immune success, or immune failure participants by flow cytometry. Representative dotplots are shown in Figure 1A. As expected, the percentage of $\mathrm{CD}^{+}$cells that were $\mathrm{Va} 7.2^{+} \mathrm{CD}_{161^{+}}$was significantly reduced in HIV-infected donors (Figure 1B). This was not due to an overall loss of $\mathrm{Va} 7.2^{+}$cells, because even though total Va7.2 $2^{+}$cells were also reduced (Figure 1C), the percentage of Va7.2 $2^{+}$cells that were $\mathrm{CD} 161^{+}$was further decreased (Figure 1D). Intriguingly, in immune failure subjects, the percentage of $\mathrm{CD}^{+}$ T cells that were Va7.2 $2^{+} \mathrm{CD} 161$ - was actually increased, compared with the percentages in both immune success subjects and healthy controls (Figure 1E). Expression of CD161 by Va7.2 $2^{+}$cells was equivalent after surface and intracellular staining in all 3 groups of donors (data not shown), verifying that loss of CD161 was not due to receptor internalization.

\section{Accumulation of $\mathrm{CD}^{+} \mathrm{Va} 7.2^{+} \mathrm{CD} 161$ - cells}

These observations led us to wonder if the loss of $\mathrm{CD} 161^{+}$cells could be due not only to cell death or traffic out of the circulation into the periphery, but also to a downregulation of the CD161 molecule itself, particularly in immune failure donors. To investigate this possibility, we examined the proportions of $\mathrm{CD}_{161^{+}}$and $\mathrm{CD} 161-\mathrm{CD}^{+} \mathrm{Va} 7.2^{+}$cells that were $\mathrm{CD} 4^{+}, \mathrm{CD} 8^{+}$, or double negative (Figure 2). Cells that were $\mathrm{CD} 161^{+}$had remarkably similar distributions, regardless of the donor source-they were mostly $\mathrm{CD} 8^{+}$, with a few double negatives and hardly any $\mathrm{CD} 4^{+}$cells (Figure 2A). In healthy controls, about half the number of $\mathrm{Va} 7.2^{+} \mathrm{CD} 161$ - cells were $\mathrm{CD} 4^{+}$, and this proportion was decreased in HIV-infected patients, particularly in immune failures (Figure 2B). Reciprocally, in the immune failure group, the proportion of $\mathrm{Va} 7.2^{+} \mathrm{CD} 161$ - cells that were $\mathrm{CD} 8^{+}$, but not double negative, was significantly increased-suggesting that there was a specific accumulation of $\mathrm{CD}^{+} \mathrm{CD} 161$ - cells within the $\mathrm{Va} 7.2^{+}$population in the absence of complete $\mathrm{CD} 4^{+} \mathrm{T}$-cell recovery. This change appears to be specific for CD8: it is unlikely to be due to overall poor CD4 ${ }^{+}$ recovery, as that would be expected to affect the percentages of both CD8 and DN cells equally, which did not occur for immune failure donors.

\section{Loss of CD161 with stimulation}

Microbial translocation is a likely driver of the persistent inflammation observed in ART-treated HIV infection [ $\underline{5}$ ], and immune failure donors have evidence of elevated microbial products and inflammatory mediators in their circulation [ $\underline{3}$ ]. MAIT cells-which recognize products of microbial metabolism [13-15] - are therefore likely to encounter their antigens of interest at a greater level in the immune failure group. To model this situation in vitro we stimulated cultures of PBMCs from HIV-negative donors with anti-CD3 and anti-CD28, then measured cell division and CD161 expression on $\mathrm{CD}^{+} \mathrm{Va} 7.2^{+}$cells 4 days later (Figure $3 \mathrm{~A}$ ). 

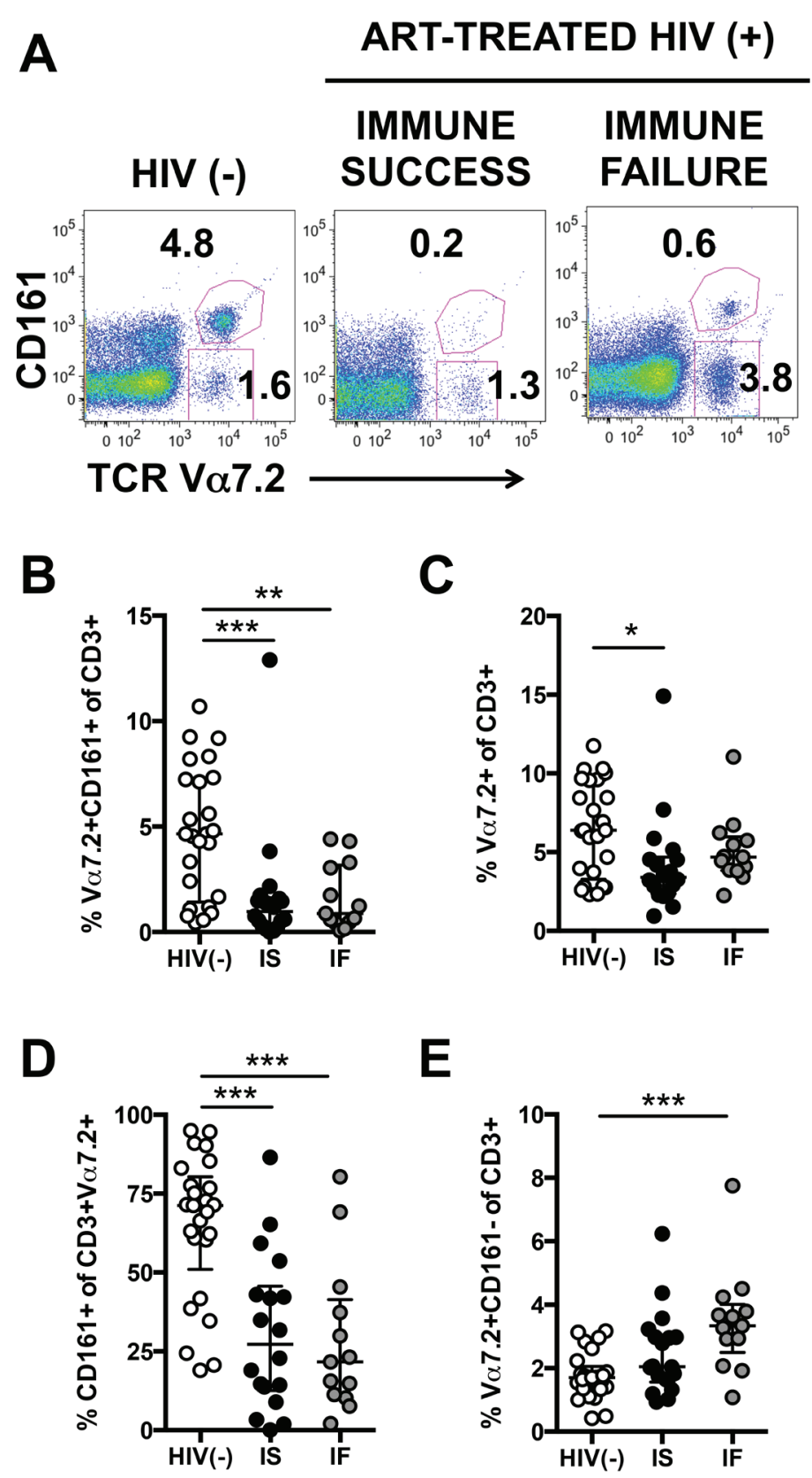

Figure 1. Loss of $\mathrm{Va} 7.2^{+} \mathrm{CD} 161^{+}$Cells in ART-Treated HIV Infection. (A) Representative plots show CD161 and TCR Va7.2 expression on $\mathrm{CD}^{+}$cells from HIV-uninfected or ART-treated HIV-infected donors. (B) The percentage of $\mathrm{CD}^{+}$cells that are $\mathrm{Va} 7.2^{+} \mathrm{CD} 161^{+}$(Kruskal-Wallis test). (C) The percentage of $\mathrm{CD}^{+}$cells that are Va7.2 (Kruskal-Wallis test). (D) The percentage of $\mathrm{CD}^{+} \mathrm{Va} 7.2^{+}$cells that are $\mathrm{CD} 161^{+}$ (Kruskal-Wallis test). (E) The percentage of $\mathrm{CD}^{+}$cells that are Va7.2 ${ }^{+} \mathrm{CD} 161$ - (Kruskal-Wallis test). ${ }^{\star} P \leq 0.05 ;{ }^{*} P \leq 0.01 ;{ }^{* \star} P \leq 0.001$. ART, antiretroviral therapy; IS, Immune Success; IF, Immune Failure. 
A
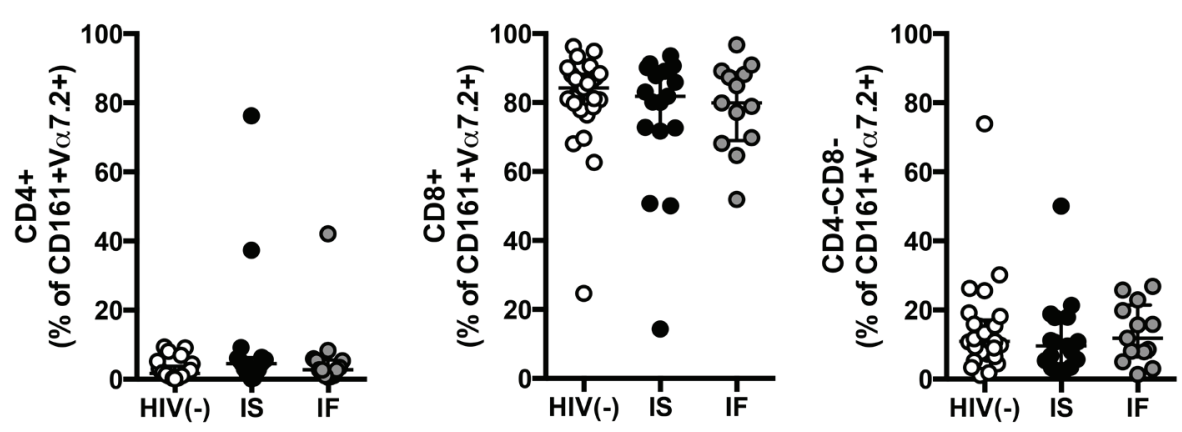

B
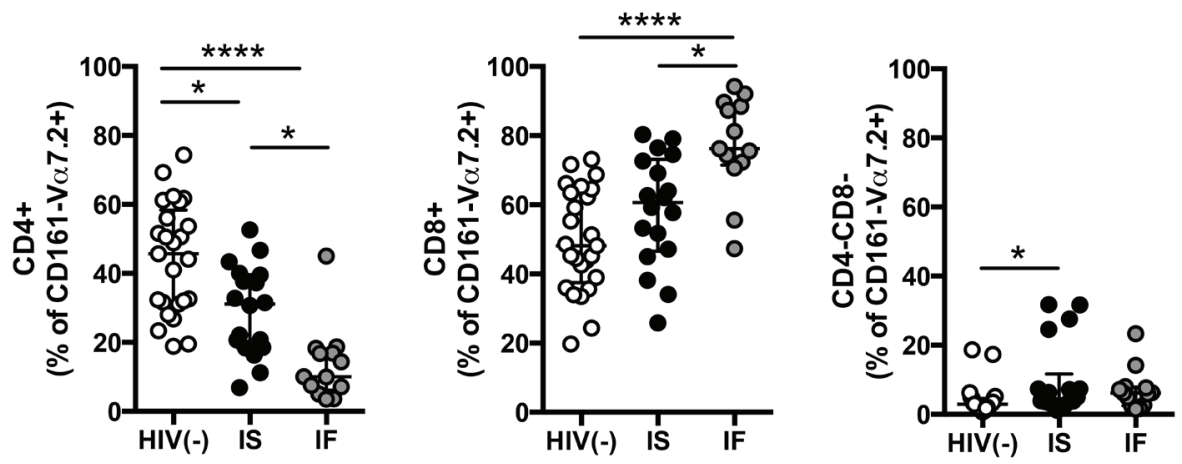

Figure 2. Accumulation of $\mathrm{CD8}^{+} \mathrm{Va} 7.2^{+} \mathrm{CD} 161$ - Cells in Immune Failure Patients. (A, left) The percentage of $\mathrm{CD}^{+} \mathrm{Va} 7.2^{+} \mathrm{CD} 161^{+}$cells that are $\mathrm{CD} 4^{+}$. (A, center) The percentage of $\mathrm{CD} 3^{+} \mathrm{Va} 7.2^{+} \mathrm{CD} 161^{+}$cells that are $\mathrm{CD}^{+}$. (A, right) The percentage of $\mathrm{CD}^{+} \mathrm{Va} 7.2^{+} \mathrm{CD} 161^{+}$cells that are $\mathrm{CD} 4-\mathrm{CD} 8-$ - All comparisons were $P>0.05$ using Kruskal-Wallis test. (B, left) The percentage of $\mathrm{CD} 3{ }^{+} \mathrm{Va} 7.2^{+} \mathrm{CD} 161$ - cells that are $\mathrm{CD} 4^{+}$ (Kruskal-Wallis test). (B, center) The percentage of $\mathrm{CD}^{+} \mathrm{Va} 7.2^{+} \mathrm{CD} 161^{+}$cells that are $\mathrm{CD} 8^{+}$(Kruskal-Wallis test). (B, right) The percentage of $\mathrm{CD}^{+} \mathrm{Va} 7.2^{+} \mathrm{CD} 161^{+}$cells that are $\mathrm{CD} 4-\mathrm{CD} 8$ - (Kruskal-Wallis test). ${ }^{\star} P \leq 0.05 ;{ }^{* * *} P \leq 0.000$. IS, Immune Success; IF, Immune Failure. 
A

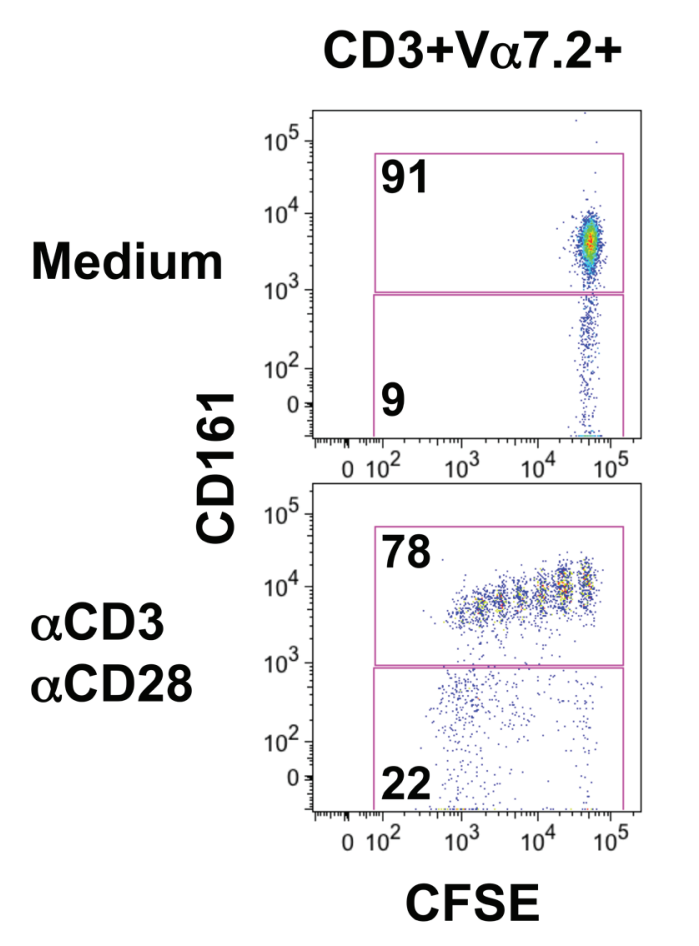

B

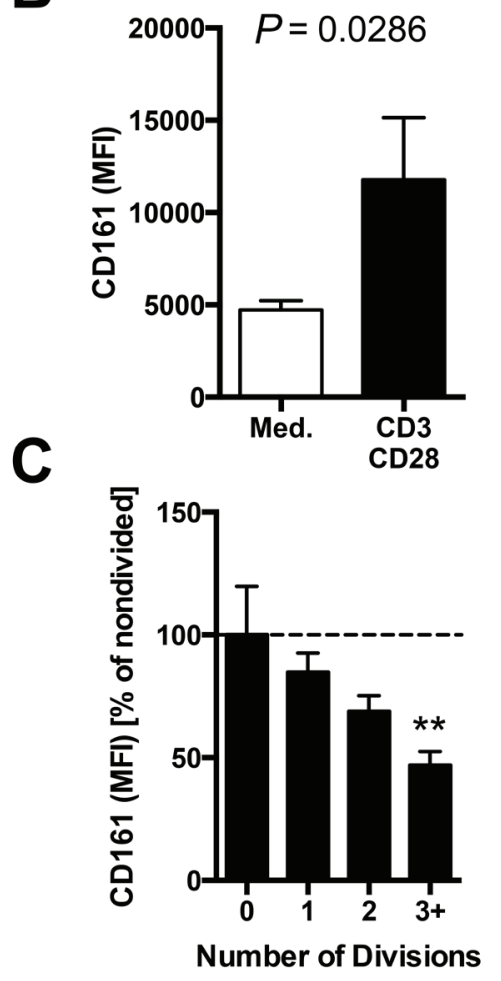

Figure 3. Cell Division and Reduction in Surface CD161 Expression Following TCR-Mediated Stimulation. (A) Representative plots show CD161 expression and CFSE dilution (proliferation) in $\mathrm{CD} 3^{+} \mathrm{Va} 7.2^{+}$ cells following 4 days culture with control medium (Med.) or stimulating antibodies to CD3 (aCD3) and CD28 (aCD28). (B) The mean fluorescence intensity (MFI) of CD161 staining on undivided CD161 ${ }^{+}$ cells as shown in (A) ( $\mathrm{n}=4$; Mann-Whitney test). (C) The MFI of CD161 staining on CD161 ${ }^{+}$cells at each round of division normalized to non-divided cells $\left(\mathrm{n}=4\right.$; Kruskal-Wallis test). ${ }^{* *} \mathrm{P} \leq 0.01$.

Interestingly, in undivided $\mathrm{Va} 7.2^{+} \mathrm{CD} 161^{+}$cells, TCR-mediated stimulation resulted in a significant upregulation of CD161 expression (Figure 3B). However, as the CD161 ${ }^{+}$cells divided, and with each subsequent division, the mean fluorescence intensity (MFI) of CD161 on the cell surface became lower (Figure 3C). Thus, MAIT cells reduce CD161 expression as they divide in response to TCR stimulation. This observation is consistent with the findings of Leeansyah et al, who demonstrated that $\mathrm{Va} 7.2^{+} \mathrm{CD} 161$ - cells accumulate in the blood and rectal mucosa during chronic untreated HIV infection, and can be generated in vitro by bacterial stimulation [21].

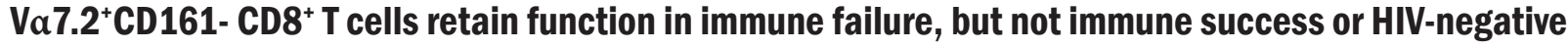 donors}

To determine if there was a functional difference in the $\mathrm{Va} 7.2^{+}$cells that were $\mathrm{CD} 161^{+}$or $\mathrm{CD} 161$-, we stimulated the TCR of PBMC preparations from each donor group for 24 hours and measured the cells for synthesis of IFN $\gamma$, a key cytokine produced by MAIT cells, particularly in response to microbial antigens $[\underline{11}, \underline{13}, \underline{21}, \underline{22}]$. In all donor groups, $\mathrm{Va} 7.2^{+} \mathrm{CD} 161^{+}$cells were nearly all 
$\mathrm{CD}^{+}$, and some of these cells produced IFN $\gamma$ (Figure 4A,B). In HIV-uninfected and immune success donors, there was a significantly lower proportion of $\mathrm{CD}^{+} \mathrm{T}$ cells producing IFN $\gamma$ in the Va7.2 $2^{+} \mathrm{CD} 161$ - subset compared to the $\mathrm{CD} 161^{+}$subset (Figure $4 \mathrm{~A}, \mathrm{~B}$ ). In contrast, Va7.2 ${ }^{+} \mathrm{CD} 161$ $\mathrm{CD}^{+}$cells from immune failure donors partially retained the ability to synthesize IFN $\gamma$ as there was no significant difference (compared to $\mathrm{CD} 161^{+}$cells) in the proportion of $\mathrm{CD} 8^{+} \mathrm{Va} 7.2^{+}$cells producing IFN $\gamma$. These data are therefore consistent with a reduction in CD161 expression on MAIT cells from immune failure donors leading to an increased population of $\mathrm{Va} 7.2^{+} \mathrm{CD} 161$ cells which retain functionality.
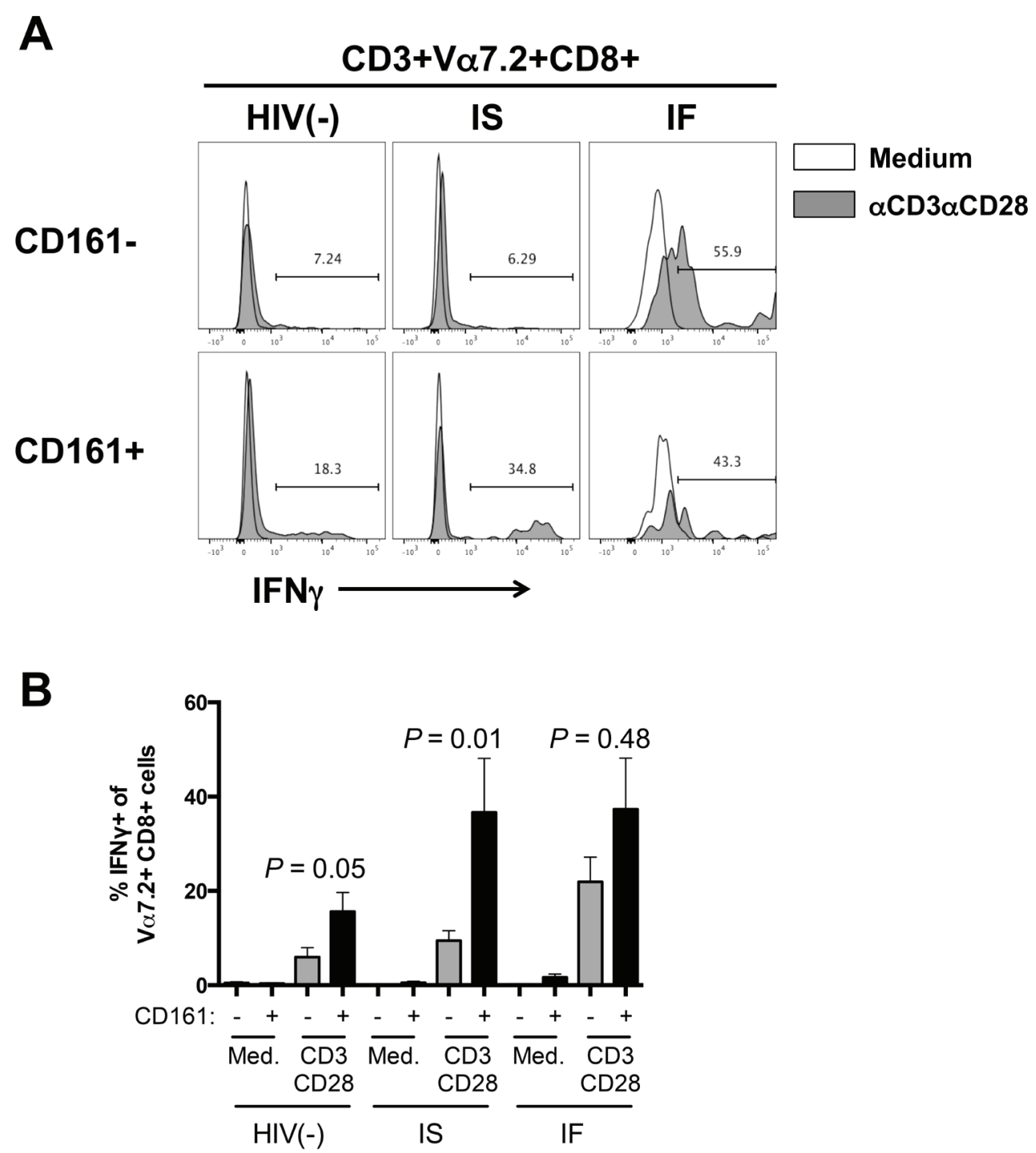

Figure 4. Sustained IFN $\gamma$ Production by Va7.2+CD161- Cells From Immune Failure Donors. (A) Representative histograms show intracellular IFN $\gamma$ synthesis by $\mathrm{CD}^{+} \mathrm{Va} 7.2^{+} \mathrm{CD} 8^{+}$cells that are $\mathrm{CD} 161-$ or $\mathrm{CD} 161^{+}$following 24 hours in culture with control medium or stimulating antibodies to CD3 (aCD3) and CD28 ( $\alpha \mathrm{CD} 28$ ). Numbers indicate the percentage of $\mathrm{CD} 8^{+}$cells that express IFN $\gamma$. (B) The percentage of $\mathrm{CD}^{+} \mathrm{Va} 7.2^{+} \mathrm{CD} 161-\mathrm{CD} 8^{+}$(gray bars) or $\mathrm{CD}^{+} \mathrm{Va} 7.2^{+} \mathrm{CD} 161^{+} \mathrm{CD}^{+}$(black bars) cells that are IFN $\gamma^{+}$ ( $\mathrm{n}=5-6 ;$ Mann-Whitney test). 


\section{DISCUSSION}

The exact role of CD161 is not clear. It appears to function as a costimulatory receptor on $\mathrm{CD} 8^{+} \mathrm{T}$ cells and NK cells, but may have opposite effects depending on the cell type [28, 29]. The ligand for CD161, lectin-like transcript-1 (LLT1), is expressed on lymphocytes and activated antigen-presenting cells (APCs) [28-30]. Although CD161 impairs IFN $\gamma$ and cytotoxicity in NK cells, $\mathrm{CD} 161$ ligation enhances IFN $\gamma$ expression in $\mathrm{CD}^{+} \mathrm{T}$ cells [29]. Consistent with the relationship between CD161 ligation and enhanced IFN $\gamma$ production, Leeansyah et al did not observe IFN $\gamma$, TNF, or IL-17 production from the Va7.2 $2^{+} \mathrm{CD} 161$ - population of untreated patients in response to overnight stimulation with fixed E. coli [21]. Here, we also observed significantly higher function in the $\mathrm{Va} 7.2^{+} \mathrm{CD} 161^{+}$subset as compared to the Va7.2 $2^{+} \mathrm{CD} 161$ - subset in cells from HIV-uninfected and immune success donors; however, $\mathrm{CD} 8^{+} \mathrm{V} \alpha 7.2^{+} \mathrm{CD} 161$ - $\mathrm{T}$ cells from immune failure donors partially retained the ability to express IFN $\gamma$ in response to TCR stimulation.

What drives the loss of $\mathrm{CD} 161^{+}$MAIT cells? It is suspected that ART-treated patients who fail to recover $\mathrm{CD}^{+} \mathrm{T}$ cells (ie, immune failure patients) also have increased microbial translocation due to excessive gut permeability [6]. MAIT cells specifically recognize bacterial or fungal vitamin $\mathrm{B}_{2}$ metabolites presented to their TCR by the MHC-I-like molecule MR1 [13-15]. An increase in circulating bacterial antigens might stimulate the MAIT cells in the bloodstream to traffic into mucosal sites where they undergo activation-induced cell death or loss of surface CD161 expression due to excessive stimulation and/or replication. We have shown that after TCR stimulation, cell division corresponds with decreased surface expression of CD161 on MAIT cells.

Based on the absence of CD161 expression, a lack of MR1 tetramer binding [23], and previously shown poor functionality [21], some researchers have proposed that the Va7.2 ${ }^{+} \mathrm{CD} 161$ - cells in chronic HIV infection are not like MAIT cells phenotypically or functionally [25]. On the other hand, Va7.2 $2^{+} \mathrm{CD} 161$ - cells from individuals with chronic untreated HIV infection, but not uninfected controls, have been shown to co-express high levels of IL-18 receptor (IL-18R) and the transcription factor PLZF-both of which promote MAIT cell functionality [31-33]. Heightened expression of these factors in both $\mathrm{CD} 161^{+}$and CD161- subsets is likely to be biologically significant since HIV + patients have higher circulating IL-18 levels than do uninfected controls [ $\underline{34}, \underline{35}]$

A likely determinant of why MAIT cells from immune success and immune failure are affected differently is in vivo cytokine exposure, as MAIT cells are susceptible to activation by several cytokines. For instance, the homeostatic cytokine IL-7 enhances MAIT-cell activation and cytokine production in response to TCR stimulation [36], and promotes MAIT-cell cytotoxicity by increasing stores of intracellular perforin and granzymes [37]. These effects could be particularly relevant in immune failure subjects who have elevated plasma IL-7 levels [7]. Similar results were seen with a combination of IL-1 $\beta$ and IL-23 [36]. Our group has shown that IL-1 $\beta$ protein is increased in the lymph node of ART-naive HIV-infected individuals [38]. Early IL-1 $\beta$ expression (prior to the initiation of ART) in the presence of systemic microbial antigens could potentially accelerate MAIT cell activation leading to exhaustion, dysregulation, and death, which is consistent with the observation that most CD161 ${ }^{+}$MAIT cell loss occurs during acute HIV infection [22]. As mentioned above, MAIT cells are highly enriched for expression of IL-18R [39], and IL-18 in combination with IL-12 induces IFN $\gamma$ expression in MAIT cells even in the absence of TCR signals [31]. Indeed, long-term stimulation of MAIT cells by bacteria-laden APCs appears to be dependent on IL-12/IL-18 signals for optimal IFN $\gamma$ induction [31]. Consistent with these 
observations, MAIT cells are activated in a TCR-independent manner by several human viral infections, and this activation is dependent on infection-induced cytokines including IL-12, IL-15, IL-18, and type I interferons [눙.

The cytokine IL-15 may prove a particularly important mediator of MAIT-cell activation during HIV infection. Serum IL-15 levels have been significantly correlated to increasing HIV viremia, low CD4 T cell count, and markers of inflammation and coagulation such as D-dimer, sCD14, CRP, and sCD163 [41]. In addition, immune failure and untreated patients have increased PBMC-derived IL-15 production compared to immune success and HIV-uninfected donors [42]. We have recently demonstrated that IL-15 levels are elevated in the lymph nodes during viremic HIV infection [43], but there are no reports on the relationship between lymph node IL-15 levels and degree of immune reconstitution in HIV patients undergoing ART. In addition, IL-15-induced production of IL-18 by monocytes could activate MAIT cells, and IL-15 treatment induces the proliferation of $\mathrm{Va} 7.2^{+} \mathrm{CD} 161^{+}$cells (our unpublished observation).

It has been suggested that the numbers of mucosal MAIT cells are reduced at a lower rate than blood MAIT cells in HIV infection, possibly indicative of MAIT-cell traffic from the circulation into mucosal sites or enhanced survival of MAIT cells located in the mucosa $[\underline{21}, \underline{26}]$. Notably, there is also a significant increase in the proportion of rectal mucosa $\mathrm{T}$ cells that are $\mathrm{Va} 7.2^{+}$but CD161- [21]. Unlike in peripheral blood, the numbers of $\mathrm{CD} 161^{+}$cells in the colon recover in patients treated with ART that have sufficient $\mathrm{CD} 4^{+} \mathrm{T}$-cell recovery [44], but it is not known if this colonic MAIT reconstitution is also observed in immune failure patients.

In HIV infection, a return of proper MAIT-cell numbers and functionality could potentially alleviate gut epithelial-barrier permeability, thereby reducing the translocation of microbial products and mitigating systemic inflammation. Therefore, it is of keen interest to explore methodology to recover MAIT-cell number in HIV infection. As noted above, there is some evidence that MAITcell function [21] and numbers in mucosal tissue [44] are restored after ART. Therapeutic administration of cytokines such as IL-2, IL-7, or IL-15 might trigger MAIT-cell proliferation or restore MAIT cell functionality, but could also induce HIV reactivation or exacerbate T-cell-driven immunopathology. Cytokine treatment might have to be coupled with blockade of IL-12/IL-18 to promote MAIT-cell proliferation while inhibiting activation. Alternatively, probiotics might alter the gut microbiota in such a way as to reduce MAIT-cell activation or induce their proliferation [45].

Although our data are consistent with a stimulation-induced loss of CD161 expression on Va7.2+ MAIT cells during ART-treated HIV infection, particularly in immune failure subjects, we cannot completely rule out the possibility that Va7.2 CD161- cells are not "ex-MAIT" cells, but rather an expansion of a separate cell population. This hypothesis has some merit, particularly because it has been shown that $\mathrm{Va7.2}{ }^{+} \mathrm{CD} 161$ - cells do not bind an MR1 tetramer reagent in healthy individuals [46] or in chronic HIV infection [려]. Notably, both studies used frozen PBMC samples, and it is unknown if freezing affects MR1 tetramer binding in CD161- cells. Alternatively, Va7.2 ${ }^{+}$CD161- cells accumulating in chronic HIV infection do not express Ki-67, suggesting that these cells are not proliferating [21] and therefore not the result of expansion of a previously minor population, but rather the result of a phenotypic conversion from $\mathrm{CD} 161^{+}$cells. In any case, expansion of $\mathrm{Va} 7.2^{+} \mathrm{CD} 161-\mathrm{CD}^{+} \mathrm{T}$ cells is an intriguing possibility worthy of further study, par- 
ticularly because activated memory $\mathrm{CD} 8^{+} \mathrm{T}$ cells expand in untreated HIV infection due to IL-15 signals [43], remain at elevated numbers for years after ART initiation, particularly in cytomegalovirus-seropositive subjects [47], and could contribute to non-AIDS-associated co-morbidities such as cardiovascular disease [표.

Future studies of immune failure patients should investigate if $\mathrm{Va} 7.2^{+} \mathrm{CD} 161$ - cells can produce other conventional MAIT cell cytokines following TCR stimulation and whether the expansion of $\mathrm{Va} 7.2^{+} \mathrm{CD} 161$ - cells is correlated to soluble markers of enhanced inflammation and coagulation (such as IFN $\gamma$, sCD14, D-dimer, sCD163, and CRP). Characterizing the functional capacity and maturation pathway of Va7.2 $2^{+} \mathrm{CD} 161$ - cells (ie, whether they are "ex-MAIT" cells or not) might provide key insights into immunopathogenesis and the increased risk of adverse clinical events in immune failure subjects.

\section{ACKNOWLEDGMENTS}

The authors wish to thank Robert Asaad, Souheil-Antoine Younes, and Sophia Zweig for help providing and preparing patient samples, and So Hee Moon for excellent technical assistance.

\section{FUNDING}

This work was funded by NIH grants P01AI076174 and UM1AI069501 (to M.M.L.), the Richard J. Fasenmyer Foundation, and the Center for AIDS Research at CWRU (P30AI036219) and its developmental and catalytic awards (to M.L.F.).

\section{POTENTIAL CONFLICTS OF INTEREST}

The authors declare no financial conflicts of interest.

\section{AUTHOR CONTRIBUTIONS}

Michael L. Freeman: Conceived the study, designed and conducted experiments, analyzed data, and wrote the manuscript.

Stephen R. Morris: Conducted experiments, analyzed data, and helped to write the manuscript.

Michael M. Lederman: Coordinated research activities and helped to write the manuscript.

\section{REFERENCES}

1. Kelley CF, Kitchen CM, Hunt PW, Rodriguez B, Hecht FM, Kitahata M, Crane HM, Willig J, Mugavero M, Saag M, Martin JN, Deeks SG. Incomplete peripheral CD4+ cell count restoration in HIV-infected patients receiving long-term antiretroviral treatment. Clin Infect Dis. 2009;48(6):787-94. PubMed PMID: 19193107. Pubmed Central PMCID: 2720023. doi: 10.1086/597093

2. Robbins GK, Spritzler JG, Chan ES, Asmuth DM, Gandhi RT, Rodriguez BA, Skowron G, Skolnik PR, Shafer RW, Pollard RB, Team ACTG. Incomplete reconstitution of T cell subsets on combination antiretroviral therapy in the AIDS Clinical Trials Group protocol 384. Clin Infect Dis. 2009;48(3):350-61. PubMed PMID: 19123865. Pubmed Central PMCID: 2676920. doi: 10.1086/595888 
3. Lederman MM, Calabrese L, Funderburg NT, Clagett B, Medvik K, Bonilla H, Gripshover B, Salata RA, Taege A, Lisgaris M, McComsey GA, Kirchner E, Baum J, Shive C, Asaad R, Kalayjian RC, Sieg SF, Rodriguez B. Immunologic failure despite suppressive antiretroviral therapy is related to activation and turnover of memory CD4 cells. J Infect Dis. 2011;204(8):1217-26. PubMed PMID: 21917895. Pubmed Central PMCID: 3218674. doi: 10.1093/infdis/jir507

4. Gazzola L, Tincati C, Bellistri GM, Monforte A, Marchetti G. The absence of CD4+ T cell count recovery despite receipt of virologically suppressive highly active antiretroviral therapy: clinical risk, immunological gaps, and therapeutic options. Clin Infect Dis. 2009;48(3):328-37. PubMed PMID: 19123868. doi: 10.1086/595851

5. Jiang W, Lederman MM, Hunt P, Sieg SF, Haley K, Rodriguez B, Landay A, Martin J, Sinclair E, Asher AI, Deeks SG, Douek DC, Brenchley JM. Plasma levels of bacterial DNA correlate with immune activation and the magnitude of immune restoration in persons with antiretroviral-treated HIV infection. J Infect Dis. 2009;199(8):1177-85. PubMed PMID: 19265479. Pubmed Central PMCID: 2728622. doi: 10.1086/597476

6. Lederman MM, Funderburg NT, Sekaly RP, Klatt NR, Hunt PW. Residual immune dysregulation syndrome in treated HIV infection. Adv Immunol. 2013;119:51-83. PubMed PMID: 23886064. doi: 10.1016/B978-0-12-407707-2.00002-3

7. Shive CL, Clagett B, McCausland MR, Mudd JC, Funderburg NT, Freeman ML, Younes SA, Ferrari BM, Rodriguez B, McComsey GA, Calabrese LH, Sieg SF, Lederman MM. Inflammation Perturbs the IL-7 Axis, Promoting Senescence and Exhaustion that Broadly Characterize Immune Failure in Treated HIV Infection. J Acquir Immune Defic Syndr. 2016;71(5):483-92. PubMed PMID: 26627102. Pubmed Central PMCID: 4788576. doi: 10.1097/QAI.0000000000000913

8. Hunt PW, Martin JN, Sinclair E, Bredt B, Hagos E, Lampiris H, Deeks SG. T cell activation is associated with lower CD4+ T cell gains in human immunodeficiency virus-infected patients with sustained viral suppression during antiretroviral therapy. J Infect Dis. 2003;187(10):1534-43. PubMed PMID: 12721933. doi: 10.1086/374786

9. Treiner E, Duban L, Bahram S, Radosavljevic M, Wanner V, Tilloy F, Affaticati P, Gilfillan S, Lantz O. Selection of evolutionarily conserved mucosal-associated invariant $\mathrm{T}$ cells by MR1. Nature. 2003;422(6928):164-9. PubMed PMID: 12634786. doi: 10.1038/ nature 01433

10. Martin E, Treiner E, Duban L, Guerri L, Laude H, Toly C, Premel V, Devys A, Moura IC, Tilloy F, Cherif S, Vera G, Latour S, Soudais C, Lantz O. Stepwise development of MAIT cells in mouse and human. PLoS Biol. 2009;7(3):e54. PubMed PMID: 19278296. Pubmed Central PMCID: 2653554. doi: 10.1371/journal.pbio.1000054

11. Dusseaux M, Martin E, Serriari N, Peguillet I, Premel V, Louis D, Milder M, Le Bourhis L, Soudais C, Treiner E, Lantz O. Human MAIT cells are xenobiotic-resistant, tissue-targeted, CD161hi IL-17-secreting T cells. Blood. 2011;117(4):1250-9. PubMed PMID: 21084709. doi: 10.1182/blood-2010-08-303339

12. Le Bourhis L, Martin E, Peguillet I, Guihot A, Froux N, Core M, Levy E, Dusseaux M, Meyssonnier V, Premel V, Ngo C, Riteau B, Duban L, Robert D, Huang S, Rottman M, 
Soudais C, Lantz O. Antimicrobial activity of mucosal-associated invariant T cells. Nat Immunol. 2010;11(8):701-8. PubMed PMID: 20581831. doi: 10.1038/ni.1890

13. Kjer-Nielsen L, Patel O, Corbett AJ, Le Nours J, Meehan B, Liu L, Bhati M, Chen Z, Kostenko L, Reantragoon R, Williamson NA, Purcell AW, Dudek NL, McConville MJ, O'Hair RA, Khairallah GN, Godfrey DI, Fairlie DP, Rossjohn J, McCluskey J. MR1 presents microbial vitamin B metabolites to MAIT cells. Nature. 2012;491(7426):71723. PubMed PMID: 23051753. doi: 10.1038/nature11605

14. Patel O, Kjer-Nielsen L, Le Nours J, Eckle SB, Birkinshaw R, Beddoe T, Corbett AJ, Liu L, Miles JJ, Meehan B, Reantragoon R, Sandoval-Romero ML, Sullivan LC, Brooks AG, Chen Z, Fairlie DP, McCluskey J, Rossjohn J. Recognition of vitamin B metabolites by mucosal-associated invariant T cells. Nat Commun. 2013;4:2142. PubMed PMID: 23846752. doi: $10.1038 /$ ncomms3142

15. Corbett AJ, Eckle SB, Birkinshaw RW, Liu L, Patel O, Mahony J, Chen Z, Reantragoon R, Meehan B, Cao H, Williamson NA, Strugnell RA, Van Sinderen D, Mak JY, Fairlie DP, Kjer-Nielsen L, Rossjohn J, McCluskey J. T-cell activation by transitory neo-antigens derived from distinct microbial pathways. Nature. 2014;509(7500):361-5. PubMed PMID: 24695216. doi: 10.1038/nature13160

16. Le Bourhis L, Dusseaux M, Bohineust A, Bessoles S, Martin E, Premel V, Core M, Sleurs D, Serriari NE, Treiner E, Hivroz C, Sansonetti P, Gougeon ML, Soudais C, Lantz O. MAIT cells detect and efficiently lyse bacterially-infected epithelial cells. PLoS Pathog. 2013;9(10):e1003681. PubMed PMID: 24130485. Pubmed Central PMCID: 3795036. doi: 10.1371/journal.ppat.1003681

17. Kurioka A, Ussher JE, Cosgrove C, Clough C, Fergusson JR, Smith K, Kang YH, Walker LJ, Hansen TH, Willberg CB, Klenerman P. MAIT cells are licensed through granzyme exchange to kill bacterially sensitized targets. Mucosal Immunol. 2015;8(2):42940. PubMed PMID: 25269706. Pubmed Central PMCID: 4288950. doi: 10.1038/ mi.2014.81

18. Kleinschek MA, Boniface K, Sadekova S, Grein J, Murphy EE, Turner SP, Raskin L, Desai B, Faubion WA, de Waal Malefyt R, Pierce RH, McClanahan T, Kastelein RA. Circulating and gut-resident human Th17 cells express CD161 and promote intestinal inflammation. J Exp Med. 2009;206(3):525-34. PubMed PMID: 19273624. Pubmed Central PMCID: 2699125. doi: 10.1084/jem.20081712

19. Eyerich S, Eyerich K, Cavani A, Schmidt-Weber C. IL-17 and IL-22: siblings, not twins. Trends Immunol. 2010;31(9):354-61. PubMed PMID: 20691634. doi: 10.1016/j. it.2010.06.004

20. Busman-Sahay KO, Walrath T, Huber S, O’Connor W, Jr. Cytokine crowdsourcing: multicellular production of TH17-associated cytokines. J Leukoc Biol. 2015;97(3):499510. PubMed PMID: 25548251. doi: 10.1189/jlb.3RU0814-386R

21. Leeansyah E, Ganesh A, Quigley MF, Sonnerborg A, Andersson J, Hunt PW, Somsouk M, Deeks SG, Martin JN, Moll M, Shacklett BL, Sandberg JK. Activation, exhaustion, and persistent decline of the antimicrobial MR1-restricted MAIT-cell population in 
chronic HIV-1 infection. Blood. 2013;121(7):1124-35. PubMed PMID: 23243281. Pubmed Central PMCID: 3575756. doi: 10.1182/blood-2012-07-445429

22. Cosgrove C, Ussher JE, Rauch A, Gartner K, Kurioka A, Huhn MH, Adelmann K, Kang YH, Fergusson JR, Simmonds P, Goulder P, Hansen TH, Fox J, Gunthard HF, Khanna N, Powrie F, Steel A, Gazzard B, Phillips RE, Frater J, Uhlig H, Klenerman P. Early and nonreversible decrease of CD161++/MAIT cells in HIV infection. Blood. 2013;121(6):951-61. PubMed PMID: 23255555. Pubmed Central PMCID: 3567342. doi: 10.1182/blood-2012-06-436436

23. Fernandez CS, Amarasena T, Kelleher AD, Rossjohn J, McCluskey J, Godfrey DI, Kent SJ. MAIT cells are depleted early but retain functional cytokine expression in HIV infection. Immunol Cell Biol. 2015;93(2):177-88. PubMed PMID: 25348935. doi: 10.1038/icb.2014.91

24. Vinton C, Wu F, Rossjohn J, Matsuda K, McCluskey J, Hirsch V, Price DA, Brenchley JM. Mucosa-Associated Invariant T Cells Are Systemically Depleted in Simian Immunodeficiency Virus-Infected Rhesus Macaques. J Virol. 2016;90(9):4520-9. PubMed PMID: 26912615. Pubmed Central PMCID: 4836342. doi: 10.1128/JVI.02876-15

25. Saeidi A, Ellegard R, Yong YK, Tan HY, Velu V, Ussher JE, Larsson M, Shankar EM. Functional role of mucosal-associated invariant T cells in HIV infection. J Leukoc Biol. 2016. PubMed PMID: 27256572. doi: 10.1189/jlb.4RU0216-084R

26. Sandberg JK, Dias J, Shacklett BL, Leeansyah E. Will loss of your MAITs weaken your HAART [corrected]? AIDS. 2013;27(16):2501-4. PubMed PMID: 23595154. Pubmed Central PMCID: 4004624. doi: 10.1097/QAD.0b013e3283620726

27. Walker LJ, Kang YH, Smith MO, Tharmalingham H, Ramamurthy N, Fleming VM, Sahgal N, Leslie A, Oo Y, Geremia A, Scriba TJ, Hanekom WA, Lauer GM, Lantz O, Adams DH, Powrie F, Barnes E, Klenerman P. Human MAIT and CD8alphaalpha cells develop from a pool of type-17 precommitted CD8+ T cells. Blood. 2012;119(2):42233. PubMed PMID: 22086415. Pubmed Central PMCID: 3257008. doi: 10.1182/ blood-2011-05-353789

28. Rosen DB, Bettadapura J, Alsharifi M, Mathew PA, Warren HS, Lanier LL. Cutting edge: lectin-like transcript-1 is a ligand for the inhibitory human NKR-P1A receptor. J Immunol. 2005;175(12):7796-9. PubMed PMID: 16339513.

29. Aldemir H, Prod'homme V, Dumaurier MJ, Retiere C, Poupon G, Cazareth J, Bihl F, Braud VM. Cutting edge: lectin-like transcript 1 is a ligand for the CD161 receptor. J Immunol. 2005;175(12):7791-5. PubMed PMID: 16339512.

30. Rosen DB, Cao W, Avery DT, Tangye SG, Liu YJ, Houchins JP, Lanier LL. Functional consequences of interactions between human NKR-P1A and its ligand LLT1 expressed on activated dendritic cells and B cells. J Immunol. 2008;180(10):6508-17. PubMed PMID: 18453569. Pubmed Central PMCID: 2577150.

31. Ussher JE, Bilton M, Attwod E, Shadwell J, Richardson R, de Lara C, Mettke E, Kurioka A, Hansen TH, Klenerman P, Willberg CB. CD161++ CD8+ T cells, including the MAIT cell subset, are specifically activated by IL-12+IL-18 in a TCR-independent manner. Eur J Immunol. 2014;44(1):195-203. PubMed PMID: 24019201. Pubmed Central PMCID: 3947164. doi: 10.1002/eji.201343509 
32. Sattler A, Dang-Heine C, Reinke P, Babel N. IL-15 dependent induction of IL-18 secretion as a feedback mechanism controlling human MAIT-cell effector functions. Eur J Immunol. 2015;45(8):2286-98. PubMed PMID: 26046663. doi: 10.1002/ eji. 201445313

33. Savage AK, Constantinides MG, Han J, Picard D, Martin E, Li B, Lantz O, Bendelac A. The transcription factor PLZF directs the effector program of the NKT cell lineage. Immunity. 2008;29(3):391-403. PubMed PMID: 18703361. Pubmed Central PMCID: 2613001. doi: 10.1016/j.immuni.2008.07.011

34. Ahmad R, Sindhu ST, Toma E, Morisset R, Ahmad A. Elevated levels of circulating interleukin-18 in human immunodeficiency virus-infected individuals: role of peripheral blood mononuclear cells and implications for AIDS pathogenesis. J Virol. 2002;76(24):12448-56. PubMed PMID: 12438570. Pubmed Central PMCID: 136707.

35. Stylianou E, Bjerkeli V, Yndestad A, Heggelund L, Waehre T, Damas JK, Aukrust P, Froland SS. Raised serum levels of interleukin-18 is associated with disease progression and may contribute to virological treatment failure in HIV-1-infected patients. Clin Exp Immunol. 2003;132(3):462-6. PubMed PMID: 12780693. Pubmed Central PMCID: 1808719.

36. Tang XZ, Jo J, Tan AT, Sandalova E, Chia A, Tan KC, Lee KH, Gehring AJ, De Libero G, Bertoletti A. IL-7 licenses activation of human liver intrasinusoidal mucosal-associated invariant T cells. J Immunol. 2013;190(7):3142-52. PubMed PMID: 23447689. doi: 10.4049/jimmunol.1203218

37. Leeansyah E, Svard J, Dias J, Buggert M, Nystrom J, Quigley MF, Moll M, Sonnerborg A, Nowak P, Sandberg JK. Arming of MAIT Cell Cytolytic Antimicrobial Activity Is Induced by IL-7 and Defective in HIV-1 Infection. PLoS Pathog. 2015;11(8):e1005072. PubMed PMID: 26295709. Pubmed Central PMCID: 4546682. 10.1371/journal. ppat. 1005072

38. Shive CL, Mudd JC, Funderburg NT, Sieg SF, Kyi B, Bazdar DA, Mangioni D, Gori A, Jacobson JM, Brooks AD, Hardacre J, Ammori J, Estes JD, Schacker TW, Rodriguez B, Lederman MM. Inflammatory cytokines drive CD4+ T-cell cycling and impaired responsiveness to interleukin 7: implications for immune failure in HIV disease. J Infect Dis. 2014;210(4):619-29. PubMed PMID: 24585897. Pubmed Central PMCID: 4172041. doi: 10.1093/infdis/jiu125

39. Billerbeck E, Kang YH, Walker L, Lockstone H, Grafmueller S, Fleming V, Flint J, Willberg CB, Bengsch B, Seigel B, Ramamurthy N, Zitzmann N, Barnes EJ, Thevanayagam J, Bhagwanani A, Leslie A, Oo YH, Kollnberger S, Bowness P, Drognitz O, Adams DH, Blum HE, Thimme R, Klenerman P. Analysis of CD161 expression on human CD8+ T cells defines a distinct functional subset with tissue-homing properties. Proc Natl Acad Sci U S A. 2010;107(7):3006-11. PubMed PMID: 20133607. Pubmed Central PMCID: 2840308. doi: 10.1073/pnas.0914839107

40. van Wilgenburg B, Scherwitzl I, Hutchinson EC, Leng T, Kurioka A, Kulicke C, de Lara C, Cole S, Vasanawathana S, Limpitikul W, Malasit P, Young D, Denney L, consortium S-H, Moore MD, Fabris P, Giordani MT, Oo YH, Laidlaw SM, Dustin LB, 
Ho LP, Thompson FM, Ramamurthy N, Mongkolsapaya J, Willberg CB, Screaton GR, Klenerman P. MAIT cells are activated during human viral infections. Nat Commun. 2016;7:11653. PubMed PMID: 27337592. Pubmed Central PMCID: 4931007. doi: 10.1038/ncomms11653

41. Swaminathan S, Qiu J, Rupert AW, Hu Z, Higgins J, Dewar RL, Stevens R, Rehm CA, Metcalf JA, Sherman BT, Baseler MW, Lane HC, Imamichi T. Interleukin-15 (IL-15) Strongly Correlates with Increasing HIV-1 Viremia and Markers of Inflammation. PLoS One. 2016;11(11):e0167091. PubMed PMID: 27880829. Pubmed Central PMCID: 5120855. doi: 10.1371/journal.pone.0167091

42. d'Ettorre G, Forcina G, Lichtner M, Mengoni F, D’Agostino C, Massetti AP, Mastroianni CM, Vullo V. Interleukin-15 in HIV infection: immunological and virological interactions in antiretroviral-naive and -treated patients. AIDS. 2002;16(2):181-8. PubMed PMID: 11807301.

43. Younes SA, Freeman ML, Mudd JC, Shive CL, Reynaldi A, Panigrahi S, Estes JD, Deleage C, Lucero C, Anderson J, Schacker TW, Davenport MP, McCune JM, Hunt PW, Lee SA, Serrano-Villar S, Debernardo RL, Jacobson JM, Canaday DH, Sekaly RP, Rodriguez B, Sieg SF, Lederman MM. IL-15 promotes activation and expansion of CD8+ T cells in HIV-1 infection. J Clin Invest. 2016;126(7):2745-56. PubMed PMID: 27322062. Pubmed Central PMCID: 4922693. doi: 10.1172/JCI85996

44. Greathead L, Metcalf R, Gazzard B, Gotch F, Steel A, Kelleher P. CD8+/CD161++ mucosal-associated invariant $\mathrm{T}$-cell levels in the colon are restored on long-term antiretroviral therapy and correlate with CD8+ T-cell immune activation. AIDS. 2014;28(11):1690-2. PubMed PMID: 24911351. doi: 10.1097/QAD.0000000000000351

45. Johansson MA, Bjorkander S, Mata Forsberg M, Qazi KR, Salvany Celades M, Bittmann J, Eberl M, Sverremark-Ekstrom E. Probiotic Lactobacilli Modulate Staphylococcus aureus-Induced Activation of Conventional and Unconventional T cells and NK Cells. Front Immunol. 2016;7:273. PubMed PMID: 27462316. Pubmed Central PMCID: 4939411. doi: 10.3389/fimmu.2016.00273

46. Reantragoon R, Corbett AJ, Sakala IG, Gherardin NA, Furness JB, Chen Z, Eckle SB, Uldrich AP, Birkinshaw RW, Patel O, Kostenko L, Meehan B, Kedzierska K, Liu L, Fairlie DP, Hansen TH, Godfrey DI, Rossjohn J, McCluskey J, Kjer-Nielsen L. Antigen-loaded MR1 tetramers define T cell receptor heterogeneity in mucosal-associated invariant T cells. J Exp Med. 2013;210(11):2305-20. PubMed PMID: 24101382. Pubmed Central PMCID: 3804952. doi: 10.1084/jem.20130958

47. Freeman ML, Mudd JC, Shive CL, Younes SA, Panigrahi S, Sieg SF, Lee SA, Hunt PW, Calabrese LH, Gianella S, Rodriguez B, Lederman MM. CD8 T-Cell Expansion and Inflammation Linked to CMV Coinfection in ART-treated HIV Infection. Clin Infect Dis. 2016;62(3):392-6. PubMed PMID: 26400999. Pubmed Central PMCID: 4706630. doi: $10.1093 / \mathrm{cid} / \operatorname{civ} 840$

48. Mudd JC, Lederman MM. CD8 T cell persistence in treated HIV infection. Curr Opin HIV AIDS. 2014;9(5):500-5. PubMed PMID: 25010897. Pubmed Central PMCID: 4211072. doi: 10.1097/COH.0000000000000086

\section{COPYRIGHT}

(C) Pathogens and Immunity 2017. This work is licensed under a Creative Commons Attribution 4.0 International License. To view a copy of this license, visit http://creativecommons.org/ licenses/by/4.0/ 